\title{
THE MODERNIZATION OF LEGAL LISTS
}

\author{
William R. White* and Irving A. J. Lawres $\dagger$
}

In modernizing our lists of legal investments the one paramount problem is to provide investment standards which are broad enough to permit of the profitable and safe investment of the vast amount of funds which are held by trustees and savings institutions. The problem is not a new one. As early as 1858 the Superintendent of Banks in New York State in submitting his annual report to the legislature called attention to the fact that savings banks were experiencing difficulty in investing their funds because of the few eligible securities. ${ }^{1}$ The legislature from time to time attempted to relieve the situation by expanding the investment authority of individual institutions to include certain classes of public securities. Continued pressure for broader investment powers eventually led in New York and in other states to the admission of railroad bonds and, finally, of the obligations of public utilities. But while lists were being gradually expanded, the amount of trust funds and savings bank deposits were ever mounting, so that the need for a sound but comprehensive list has never been fully satisfied.

In recent years the problem has been complicated by a severe business depression and by factors which, in many instances, are traceable to the policies of the federal government, the states or their municipalities. The plight of the railroads has become a matter of common knowledge. The solution of their problems requires not only an improvement in business, but also a plan of cooperation with the government looking toward the elimination of duplicating facilities and the adoption of more efficient policies of operation. The lack of sound financial practices on the part of many political subdivisions has resulted in defaults and refunding operations, while public utilities are faced in some cases, either by actual government competition, or

- A.B., Bucknell University, I926; LL.B., Columbia University, 1929. Superintendent of Banks, State of New York; President, National Association of Supervisors of State Banks.

+A.B., Marquette University, 1924; M.A., Columbia University, 1928. Confidential Assistant to the Superintendent of Banks, State of New York.

1 "That $\$ 6,772,175$, including interest on undrawn deposits, should seek investment in this class of institutions during the past year, and that the payments to depositors should have reached the amount of $\$ 21,789,493$, while their deposits during the same period were $\$ 26,514,144$, is a result wcll calculated to attract the attention of the philanthropist as well as the legislator, as he contemplates the apparent increase from year to year, of this immense trust fund.

"Already complaints reach this department of the inconvenience and difficulty of investing this grcat fund; and applications are made to the Legislature to admit the introduction of other securities than those allowed by the respective charters under which the various trustees are acting." REPORT OP THE [N. Y. State] Superintendent of Banks Relative to Savings Banks, 1858, p. 2. 
by the threat of such competition. The mortgage field, which has long been the principal source of income for trustees and savings banks, has been seriously affected. Unemployment has resulted in a dearth of new mortgages, in a multitude of foreclosures, and in a high percentage of arrears in taxes and interest upon existing liens. As a consequence of these developments, a tremendous volume of funds has been invested in government obligations. ${ }^{2}$ Even in this field, however, the investor must weigh the factors of a low yield, a mounting government deficit and the possibility of depreciation resulting from an increase in money rates.

While many trustees are disturbed by the situation confronting them, it is argued by some that during a period of social and economic readjustment it is futile to attempt a general revision of our investment standards. This opinion prevailed quite generally in 1932 and 1933 , but as time has passed we have found that depressed business conditions have brought to the fore numerous investment problems of a fundamental nature. It is to these problems which are likely to be obscured in times of prosperity that we should now direct our attention.

Briefly stated, it was the early rule of the common law that a trustee was required to exercise sound discretion in making investments. ${ }^{3}$ The application of this standard resulted in certain jurisdictions in what is known as the Massachusetts rule. The essence of this rule is that the courts do not attempt to prescribe with exactitude the securities in which a trustee may invest. On the contrary, the trustee is permitted a wide range of latitude in which to exercise his discretion, provided he acts with prudence and in good faith. ${ }^{4}$

\section{Changing State Policies}

In New York the common law evolved a much narrower rule than in Massachusetts, with the result that in the Empire State investments were confined to govern-

\footnotetext{
2 "The world's outstanding example of safety-secking capital comes from India, where princes preserve their wealth in the indestructible form of gold and jewels-and the Indian masses starve. Safety, one need scarcely be reminded, is not characteristic of any new or rapidly expanding enterprise. On the contrary, safety is the characteristic of the relatively least productive securities, of the so-called "legal investments,' of liens on fixed property whose value is already established and proved, and of the government bonds. In investments and enterprises such as these capital is content with a return of from one to four per cent; and the more capital falls back on this kind of return, the slower must be the expansion of the economy." Fortune, May, 1938, p. 58.

${ }^{3}$ At common law in England it was for many years the rule that trust funds could be invested in government securities only. Investments in stock of corporations were not allowed unless expressly authorized by the instrument creating the trust. See (rg21) 69 UnIv. of PA. L. Rev. 189. Bogert states that fiduciary investments in England were limited by court order to government or bank annuities. He further says that doubt as to the soundness of real property securities was solved by the passage of a statute validating such investment in realty within the United Kingdom and later English legislation has greatly widened the field of trust investments. Sce 3 Bogert, Trusts AND Trustees, (1935) \$163, with notes citing the English statutes. The University of Pennsylvania Law Review note cited says that the common law rule in England was followed so strictly that Parliament finally interposed and by statutes passed during the reign of Queen Victoria it authorized the investment of trust funds in the stock of the Bank of England or of Ireland or in mortgages upon frechold or copyhold estates. Subsequent legislation in England has continually enlarged the scope of the legal list and finally the English Trustees Act of 1925 (set out in Bogert) was enacted which contains an unusually broad legal list wherein fiduciaries may invest.

- Grange, Staub and Blackford, Wills, Executors and Trustees (ig33) 337.
} 
ment bonds and first mortgages on improved real property. Before many years had passed, however, the legal list as so established was found to be inadequate to meet the needs of an ever increasing accumulation of trust funds. In I897 an act was adopted permitting investments -to be made in the obligations of cities located in New York ${ }^{5}$ and in 1902 the more important step was taken of permitting trustees to purchase any of the securities authorized as investment for savings banks. ${ }^{\circ}$ While this amendment to the statute added certain classes of railroad bonds and public securities to the list eligible for purchase by trustees, it was by no means a solution of the problem, since the savings banks list itself was already subject to pressure due to mounting deposits in savings institutions. ${ }^{7}$

It is interesting to observe that, while New York was compelled to abandon the rule of her common law, shè was unwilling to go the whole distance and adopt the principle laid down in Massachusetts. Instead, she chose the convenient course of extending the investment authority of trustees to a list of securities already in existence. This was done without regard to the fact that the savings banks list had originated to serve the needs of a group of institutions which were founded as mutual benefit associations and which were operated in most cases, not by full-time paid executives, but by laymen who found it possible to donate a portion of their time to this public service. ${ }^{8}$ Under the circumstances, it was not surprising that management was strictly limited in the selection of investments. While the list was later expanded from time to time, the principle of limitation which characterized its origin was never abandoned.

So long as trust functions were performed mainly by individuals, usually laymen, there was some reason for maintaining consistency in the investment powers of

N. Y. Laws 1897 , c. 417 .

-N. Y. Laws xg02, c. 295.

I "In the six years covering my incumbency of the office of Superintendent of Banks, constituting a natural period for comparison, the savings banks have gained $\$ 348,486,043.37$ in resources, or a larger amount than in the previous fourteen years, and the trust companies $\$ 576,773,865.75$, which is nearly one and a half times their entire combined accumulations for all the years prior to 1896 . That these stupendouis increases have not been made at the expense of other banking corporations is evidenced by the fact that the National and State discount banks in the State have increased their resources in the same time by about eight hundred million dollars. The present total assets of these three classes of institutions approximate four thousand millions of dollars, over forty per cent of which has been accumulated in six years. ... .

'New York's system of savings banks is the best in the world, and it should be our pride and care to so maintain it. But with deposits increasing at the rate of sixty or seventy million dollars a year, if the field for investment were held unchanged, there would follow of necessity an appreciation in the price of such securities until in time it became prohibitive. . . " REPORT OF THE [N. Y. STATE] SUPERINTENDENT of Banks, Relative to Savings Banks, T"rust Companies, Safe Depost Conpanies, and Miscellaneous Corporations, igor, pp. 5 , 31 .

8 "First. Savings banks being in a measure charitable institutions, they lose their distinctive character in this respect if those who conduct and manage them have any other than perfectly disinterested relations to their trust.

"Second. If a trustee may be at the same time an officer, enjoying a comfortable salary, the purity of motive implied in the acceptance of an unpaid position of care and responsibility, which should be above possible question, is at once sullied with doubts and suspicions of selfish and interested designs." Emerson W. Keyes, Deputy Superintendent of Banks, N. Y. State, Special Report on Savings Banks (1868) 138 .

However, Chapter 136 of the Laws of 1858 authorized the payment of a salary to the president of any savings bank in New York, Brooklyn and Buffalo, but provided that "no person shall be elected or remain such president whose professional or other engagements shall prevent his regular and faithful attendance to the duties of his office." 
savings banks and fiduciaries. In 1902, however, when this principle of consistency was reaffirmed by the legislature, a factor was present which might well have dictated a somewhat different course than that which was adopted, for by this time corporate fiduciaries had come to occupy an important position in the financial world. Unlike savings banks, trust companies were organized for private profit. They were managed by paid executives and many of them retained the services of investment experts. These facts, however, apparently never appealed to the legislature as justifying an expansion of the discretionary powers of corporate trustees. On the contrary, this class of fiduciaries has been confined to the list which was designed and maintained primarily to serve the needs of institutions for savings. Whenever investment standards have been changed, the views of savings banks, as expressed through their association, have been accorded great weight by the legislature. On the other hand, trustees, because of their reluctance to trespass in a field where the rights of savings banks have become firmly established, have exerted little or no influence in the development of the list. In recent years the Trust Companies Association has expressed dissatisfaction with the present system and has considered the advisability of applying to the legislature for a separate list. Provision for such a list would no doubt encourage the great corporate trustees in New York to take a more active interest in the many public problems involved in maintaining modern investment standards.

As a result of cooperation between the legislature and the Bankers Association, Pennsylvania, in 1935, adopted a new statute which substantially broadened the list of eligible securities. ${ }^{9}$ Originally the Keystone State followed the narrow common law view which confined trust investments to government bonds and first mortgages on real estate. Like New York, however, she soon found this rule to be unworkable and was obliged to effect modification through legislation. In I824 a statute was passed authorizing the Orphans Court on petition to direct investment in the debt of the United States, of the Commonwealth of Pennsylvania, of the City of Philadelphia, or in real securities. The list as so established was periodically expanded from about 1850 until it included the obligations bf certain other municipalities within the State of Pennsylvania and also of the Pennsylvania and Reading railroads and of the Lehigh Coal and Navigation Company. Presumably this type of legislation led to general dissatisfaction, for, when the Constitution of 1873 was adopted, it prohibited the General Assembly from authorizing investment in bonds and stock of any private corporation. Thereafter, legislation permitted investments in various governmental obligations. As a rule, the state courts attempted to interpret the constitutional restriction of 1873 broadly. This was apparently founded on the fact that courts sympathized with the fiduciary who was faced with the problem of investing increasing volumes of trust funds within the limits of a narrow list. In I929 requests were made to the legislature by the Pennsylvania Bankers Association for a relaxation of the constitutional provision. An amendment was voted at the polls in

${ }^{\circ}$ Pa. Stat. Ann. (Purdon, 1935) 8801. 
1933, which repealed the constitutional limitation of 1873 and provided that the General Assembly might from time to time prescribe investments for fiduciaries. Pursuant to this amendment, an act was passed authorizing fiduciaries to invest in a fairly broad list of securities. Pennsylvania thus provided separate lists for savings banks and trustees. While there is no substantial difference in the scope of the two lists, it appears that the Commonwealth has taken a progressive step in recognizing the investment problems of trustees as sufficiently important to command the attention of the legislature. Moreover, since the act referred to was adopted largely upon the recommendation of the Bankers Association, it may fairly be assumed that in the future the views of corporate trustees will be considered whenever amendments are under discussion.

The need for cooperative action between the state and mutual savings institutions with respect to investments has recently been recognized in two jurisdictions. An act adopted by the Maine Legislature in I937 authorizes the Bank Commissioner, upon the written recommendation of a special committee of the Savings Banks Association, to expand the list to include certain railroad securities which he deems suitable for investment by savings banks. ${ }^{10}$ An amendment passed this year in New York empowers the State Banking Board, upon the application of not less than twenty savings banks or of a trust company all the stock of which is owned by savings banks, to add to the regular list corporate interest-bearing obligations not otherwise eligible for investment. ${ }^{11}$ While the lists in both these states are intended primarily for the use of savings institutions, the principle might readily be extended to permit trustees to make recommendations relative to the lists from which they are required to select investments.

The statutes enacted in Maine and New York are also deserving of consideration because they provide for a degree of flexibility which is lacking in states where specific investment standards are fixed by legislation. Principally to achieve such flexibility, New Hampshire has gone even further than Maine or New York by providing for a Board of Investment which has authority, acting in conjunction with the Banking Commissioner, to prescribe within certain general limits the securities in which savings banks may invest.

In each of the three states mentioned, the principle of permitting a state official or board to exercise discretion in compiling the legal list was adopted because of the difficulty encountered in attempting to prescribe fixed statutory standards which operate efficiently to provide a sound list of securities. To devise statutory tests which admit a high percentage of all sound securities without also qualifying a substantial volume of questionable obligations has been found to be a difficult, if not impossible, task. A study being conducted for the Brookings Institution by Professor George W. Edwards, of the College of the City of New York, illustrates the in-

\footnotetext{
${ }^{10}$ ME. Rev. Stat. (1930) c. 57, \$27, as amended by Me. Laws 1931, 1933, 1935 and 1937.
}

${ }^{1} \mathrm{~N}$. Y. Laws 1938, c. 684 . 
effectiveness of the present tests applicable to railroad securities and emphasizes the difficulty of devising acceptable statutory standards. ${ }^{12}$

\section{Ratrroad Standards Are InEFfective}

Professor Edwards divided the railroads into two classes, good and poor. With the good roads he included all those whose bonds at no time during the depression showed a yield above $6 \%$, while the poor road group was restricted to those whose securities either had a yield above 10\% or which went into default. Professor Edwards then subjected these roads to various tests. As the requirements of the various states are not consistent, Professor Edwards, for the purpose of his study, selected the most stringent test of each type employed by any state. The data given cover the years 1923 to 1934 inclusive. Without attempting here to evaluate the basis of dividing the roads into good and poor, it is interesting to observe the effectiveness of each test in excluding the securities of the poor roads from the legal list and at the same time admitting to the list the obligations of the good roads.

One of the tests found in many statutes relates to minimum single track mileage of 500 miles. During the twelve-year period studied, this test excluded $20 \%$ of the good roads and admitted $33 \%$ of the poor ones, with practically no annual variation from these figures. Another test requires a minimum gross operating revenue of $\$ 10,000,000$ or $\$ 15,000,000$. On the basis of the latter figure, $73 \%$ of the good roads qualified up until 1930 , and about $60 \%$ after 1930. More than half the poor roads, however, met this requirement until 1929 and during the depth of the depression the figure never fell below $22 \%$.

The requirement that a road pay $4 \%$ dividends on its capital stock was more satisfactory. It admitted to legal status $87 \%$ to $94 \%$ of the good roads prior to $x 93$, but these figures fell off sharply to $27 \%$ in I933. About a third of the poor roads met the dividend test from 1926 to $1929,41 \%$ in $1930,15 \%$ in 1931 , and $0 \%$ in the three subsequent years.

The test prescribing that cash dividends must be equal to at least one-third of fixed charges qualified a high percentage of good roads, about $87 \%$ in prosperous years and approximately $60 \%$ during I932 and ' 33 . During I 128 , ' 29 and ' $30,44 \%$ of the poor roads were also eligible under this requirement, but only $4 \%$ qualified during 1932 , ' 33 and ' 34 . The 1.5 ratio of earnings to fixed charges admitted nearly all the good roads immediately prior to $\mathrm{x} 93 \mathrm{r}$, but in 1925 it also qualified $78 \%$ of the poor roads. In 1932 the percentage of good roads eligible under this test dropped to $53 \%$ and that of the poor roads to $3 \%$.

The requirement that gross earnings be 5.0 times fixed charges admitted nearly all the roads, good and poor, during the prosperous years. During the depression a large percentage of the good roads and about one-third of the poor ones continued to meet the test. Another requirement, that total debt shall not exceed 3.0 times

2 For a presentation of the results of this study, see Edwards, New Standards for Railroad Securities (1937) Trust Companies I74. 
capital stock, qualified most of the good and poor roads in time of both prosperity and depression.

This study made by Professor Edwards, with the assistance of a staff of WPA workers, was for the purpose of ascertaining if more satisfactory statutory tests could be devised. Commenting on the results of his attempt to find new and more effective tests, he said, ${ }^{13}$

"Most of these tests proved to be as ineffective as the legal requirements when judged by actual investment experience. . . . Most startling of all was the apparent uselessness of all the ratios measuring the burden of debt and the nature of the capital structure of a railroad such as the debt per mile, ratio of property to debt, and the ratio of debt to total capitalization. . .."

Professor Edwards, however, found several tests, based largely upon income, which he believes are somewhat more effective than present standards. Apparently the most satisfactory of these is a minimum freight density requirement of $1,200,000$ ton miles. The author points out, however, that, even on this basis, one-third of the poor roads would have qualified in 1929 , and $13 \%-20 \%$ of the good roads would not have qualified during pre-depression years. According to some of the other proposed tests, from $20 \%$ to more than $50 \%$ of the poor roads would have qualified prior to 1930 .

Professor Edwards' study provides excellent evidence of the difficulty of devising satisfactory statutory tests even with respect to the basic facts which can readily be ascertained in the case of all railroads. Obviously, it is even more difficult to apply rigid tests to other factors of a more intangible nature. For example, it seems impossible to provide standards giving effect to probable future developments involving changing tastes, shifts of population, and new means of transportation. Nevertheless, it is factors such as these which must be considered if a security is to be admitted to the legal list before it is selling at a high premium or dropped before it has greatly depreciated in value. ${ }^{14}$

\footnotetext{
is Id. at 175 .

"One of the principal criticisms levied against the legal list is that it is an incentive to buying at the "top" and selling at the "bottom."

"Let us suppose that a trustee in I92I invested the corpus of a new trust in 'legals' at an average price of 95. The entire list appreciates to an average of 105. The trustee may shift the investment, take his profits and look for re-investment opportunities. He will hardly find them within the legal list, for all bonds are likely to be up. Possibly he turns to mortgages. But he is under no compulsion to do anything. On the other hand, let the bond list decline, let the earnings of the obligors fall below the legal standard and the security forthwith becomes non-legal. The trustee may retain it, but it is his own responsibility if he does. By the time this question arises the bonds will have depreciated considerably in price. And here is a fundamental tlaw in the statutory preseription of investment standards. An incentive is given for selling out at a low price but no incentive is given for selling out at a high price. Now as a matter of investment management any rule or condition which provides $2 n$ incentive to dispose of first lien bonds at a time of the obligor's adversity and no corresponding incentive to dispose of them at the beight of its prosperity is fundamentally unsound. It is conducive to buying at the top and selling at the bottom. An investment manager tries to do exactly the opposite." Woodruff, Legal and Investment Standards of Trustees (1935) 4 FordhaM L. REv. 4 r2.
} 


\section{Municipal Tests Aiso Fail}

In the field of municipal securities, it is also difficult to devise effective statutory tests. ${ }^{15}$ A large percentage of the states authorize trustees or savings banks to invest in the obligations of their own political subdivisions without restriction or limitation. Standards imposed usually deal with the municipalities of other states and relate principally to population, taxing power and amount and character of debt burden.

There seems to be no generally accepted rule relative to the minimum population which a city or village must have before its obligations may qualify as legal investments. For example, New York imposes no population test with respect to its own municipalities, but requures a city in a state adjoining New York to have at least Io,000 inhabitants, and provides that cities located in other states shall have a population of at least 30,000 . It seems impossible to reconcile these three different rules, or to suggest any other minimum population requirement which would serve as an effective and accurate standard. While a considerable number of small communities have experienced financial difficulties since 1930 , it is also a fact that a substantial number of small municipalities in good financial standing have been unable to qualify their obligations because of their inability to meet minimum population standards. The number of inhabitants should unquestionably be taken into account in appraising the credit standing of a municipality, but this factor should be considered in connection with others and not as an independent qualification to be determined by a rigid statutory requirement. Much more important than the number of inhabitants are the type and trend of population, factors which cannot be reduced to simple, inflexible formulae.

The authority of a community to levy taxes should undoubtedly be considered in setting up investment standards. Some states require that a municipality in order to qualify its obligations as legal investments shall have unlimited power to tax real property for the payment of such obligations. Such provisions have recently attracted considerable attention in view of the fact that certain states have within the past few years imposed tax limitations, while in other states proposed limitations are being discussed. Hence the rule requiring unlimited taxing power tends to bar an

${ }^{25}$ Professor Edwards is now making a study of municipals and utilities, which will be completed next year. For the purpose of this article, he has kindly allowed us to quote him as follows:

"In general, our study shows that the legal tests for utility bonds had a much better investment experience than those for railroad bonds. However, the fundamental defect in the legal tests for utility bonds is their failure to recognize financial differences in the various classes of utilities. It is impossible to set up one set of standards for all classes of utility bonds, and so our recommendations will include different tests for the different classes of this group.

"Our study further shows that the legal tests for municipal bonds are very incomplete. In general these tests were based on the theory that public credit could be accepted without question, and that there was no need of careful study of municipal obligations. The unfavorable trend of municipal credit in recent years and the unhappy investment experience of thousands of municipal bonds have demonstrated the need of applying specific tests to this class of bonds. Fortunately, this group lends itself to exact measurement and quantitative tests even better than corporate bonds, and we have been able to establish some tests which should prove useful. We have made a tentative exploration in the field of industrial bonds, but as yet have arrived at no definite conclusions. Our preliminary study shows that the field is promising and offers justification of industrial bonds in the legal list. The lack of standardization of accounting in this field makes difficult the task of formulating exact tests." 
increasing volume of municipal securities. In the main, this test is sound because we appear to be going through a period in which the number of services rendered the public is being constantly increased. A rigid tax limitation, therefore, may at some future time prevent a municipality from levying the necessary taxes to meet an expanded budget. Unlimited taxing power, however, is no guarantee of sound municipal credit. There is little satisfaction to be found in the fact that a community has unlimited taxing power if deficits have been accumulated, due to a demonstrated inability to collect the taxes levied.

The difficulty of determining by statutory standards when a community has become over-extended in debt has been emphasized by recent experience. The two most important phases of this problem relate to (I) determining what obligations should be included in computing municipal indebtedness and (2) the yardstick to be used in deciding whether the indebtedness so calculated is unduly heavy.

It would appear to be a relatively simple task to compute the total indebtedness of a municipality. Nevertheless, the application of the formula laid down pursuant to the New York statute has produced results which seem contrary to the elementary principles of arithmetic, for it has been held that notes issued in anticipation of the collection of delinquent taxes may be excluded from the computation of indebtedness. This legal ruling was based upon the theory that delinquent taxes are an asset specially pledged to the payment of the notes and that consequently they place no further general burden upon the community. Experience has proved this theory to be unitenable in practice. A number of municipalities in one eastern state suffered serious financial difficulty because of the large accumulation of debt of this character. $\mathrm{Had}$ these items been included as "indebtedness" in determining the status of the municipalities in question, their obligations would have become non-legal before serious financial difficulty was encountered. Instead, these obligations remained on the legal list until the credit of the issuing municipalities had become impaired, and in at least one instance removal from the list followed adoption by the city of a conservative plan providing for the funding of its floating debt and a pledge to maintain operations thereafter on a cash basis. This experience in the application of the New York statute is worthy of note as illustrating that a municipality in financial difficulty sometimes resorts to practices not contemplated by a legislature in prescribing investment standards. Had there been no statute upon this point justifying a contrary view, sound investment principles would have dictated the inclusion as indebtedness of notes issued in anticipation of the collection of delinquent taxes.

A second phase of the problem of how indebtedness is to be computed relates to obligations issued for the financing of municipal utilities. Present provisions usually exclude water debt, which is justifiable to the extent that such debt is supported by the earnings of the water department and is not dependent upon tax collections. It is also reasonable that debt incurred for the construction of municipal lighting systems should be excluded to the extent that such debt is self-supporting. This principle, however, should not be extended to include all debt incurred in connection with 
municipal projects merely because provision is made for the collection of fees or charges other than taxes for the services rendered. The number of municipal undertakings which have proved financial failures indicates the wisdom of a strict rule in permitting exemptions of debt incurred for specific purposes. Generally speaking, this principle is one which can be effectively prescribed by statute. The difficulty is that any debt exemptions permitted by the statute are apt to be applied with equal force to all municipalities without regard to the varying degrees of success enjoyed by the utilities whose debts are exempted.

But even assuming that effective provisions of law can be written prescribing satisfactory methods for computing indebtedness, we are still faced with the problem of determining when in the case of any municipality such indebtedness is reasonable. Assessed valuation of real estate is the basis usually employed for determining the amount of debt which a city can safely support. The difficulty with this test is that it leaves no discretion to the authority compiling the legal list to take into consideration variance in practice in the evaluation of real estate for tax purposes. Cases which have come to light, illustrating that assessed valuation is not always a reliable index, have caused consideration to be given to the enactment of a standard relating total debt to population. A uniform per capita debt limit, however, would probably not be acceptable, because it is generally conceded that large cities can support a greater per capita indebtedness than villages or small cities. In any event, both of these standards are open to the criticism that they fail to take into account many factors which bear directly upon the question of how great a debt a particular community is able to support. It can, in fact, be said of all provisions prescribing the standards applicable to municipal obligations, that they fail to permit an exercise of discretion with respect to such important factors as transportation facilities, diversification of industry, community wealth, and the character of municipal management. If factors such as these could bë taken into consideration in addition to the tests prescribed by the statute, the obligations of communities apparently headed for financial diffculty might be removed from the list before they suffered serious market depreciation, and the bonds of other municipalities might safely be added to the list, even though the issuing body failed to meet one of the technical statutory standards.

\section{An Investment Board as a Means of Achieving Flexibility}

We might go on to discuss sections of law dealing with other classes of securities, but such an examination would only serve to emphasize the weakness which we have found in the tests dealing with railroads and municipalities. It is true that some of these defects are of a technical nature and could no doubt be cured by a careful revision of existing statutes. The basic weakness, however, that of inflexibility, can apparently be corrected only by a fundamental change which would permit the exercise of discretion in compiling legal lists. Perhaps the solution lies in abandoning statutory tests and adopting the Massachusetts rule, which permits wide discretion to the trustee but holds him to reasonable standards of diligence and. prudence 
in the selection of investments. It is doubtful, however, that states such as New York, where the concept of the legal list is deeply rooted in law and practice, would be willing to make a decisive change in a matter of such great importance. The alternative which has been suggested is the plan which is being tried in those states where a public official or board is vested with broad discretion and responsibility to select suitable securities for savings bank or trust investment. ${ }^{16}$

The principal arguments advanced for this method of providing a legal list may be summarized as follows:

I. Assuming the appointing officer acts intelligently and in good faith, the person or persons selected to compile the legal list will be fitted by experience to assume such a responsibility. A legislature, unless it happens to have investment experts among its membership who are willing to keep in constant touch with the problem of legal investments, must rely almost completely upon the recommendations of independent groups or individuals.

2. A board is able to act with reasonable promptness in effecting changes in the list, whereas the legislative process is generally slow, due in part to the fact that some forty of our state legislatures do not meet more frequently than biennially.

3. It is difficult, if not impossible, to prescribe fixed tests which will work with a high degree of accuracy. General standards, if sufficiently strict to exclude unsound securities, often disqualify otherwise desirable investments because the issuing body fails to meet one of the prescribed tests. Conversely, some securities which are undesirable from the standpoint of a sound investment policy manage to qualify because they meet the technical minimum standards. It is argued that this difficulty is avoided by entrusting the compilation of the list to a board which can consider each issue of securities upon its merits.

4. A board can consider all of the factors affecting the desirability of a particular security. Statutory tests are based upon the past record of the issuing municipality or corporation, but they take no cognizance of future probabilities suggested by economic trends.

The two principal arguments which are most frequently advanced in opposition to the idea of permitting the exercise of discretion to a public official or board in compiling a legal list are as follows:

I. It is contended that positions on any such board would, in most cases, be filled by politicians not qualified to judge securities but susceptible to influence exerted by special interests.

I0 "A bill authorizing savings banks to invest in bonds of any corporation or individual secured by first mortgage upon property in this State, and in other good securities (excepting bills of exchange, promissory notes, deposits of personal property and stocks, to which by law the personal liability of stockholders at. taches), which might be approved by the Superintendent of the Banking Department, the Governor, Comptroller and State Treasurer, or a majority of them;' passed the Legislature of 1883 , with little or no opposition. Upon calling the attention of the several savings banks to the fact that this bill needed but the signature of the Governor to become a law, I was enabled to present the carnest protest of repre. sentatives of savings banks holding $\$ 449,000,000$ of the total $\$ 459,000,000$ of resources in the banks at that time, which resulted in the executive veto." REport of THE. [N. Y. STATE] Superuntendent op Banks Relattve to Savings Banks, 1885, p. 25 (italics ours). 
2. It is argued that a security mentioned on a list compiled by a board acting with discretion is apt to be regarded as bearing the stamp of approval of the state and therefore as not requiring examination by the investor.

These two criticisms are undoubtedly worthy of consideration but neither presents an insuperable difficulty. To insure against the possibility of having unqualified persons appointed, provision might be made authorizing corporate trustees to select candidates from whom the Governor would be required to appoint the members of the investment board. To avoid further the possibility of the positions being utilized for patronage purposes, the members could be prohibited from receiving any remuneration other than expenses actually incurred in connection with their duties. ${ }^{17}$ Such a plan should provide, however, for a staff of adequately compensated experts having the protection of civil service. This staff would compile data and prepare recommendations for consideration at the periodic meetings of the investment board. As a safeguard against the activities of pressure groups, the statute might provide that the board could list securities only upon application of a specified number of corporate fiduciaries. In any event, the statute should sanction the submission to the board of recommendations by corporate trustees.

The second criticism of the principle of authorizing a board to select a legal list involves the question of whether such a plan can be set up in a manner to avoid assumption by the state of responsibility which properly belongs to the trustee. It has been argued with some justification that the existence of legal lists has sometimes encouraged savings bank management to select investments from those enumerated, without thoughtful investigation. Such practices, however, have no doubt been encouraged in some cases by statutes which tend to minimize the responsibility of management in selecting investments. ${ }^{18}$ Moreover, the savings bank trustee, although his activities are supervised by the state, is not directly responsible to the beneficiary in the same manner as the ordinary fiduciary, who must always be prepared to appear in court and justify his actions in the light of statutes and court decisions.

It therefore rests with legislatures and with courts to adhere to a policy which places proper responsibility upon the trustee to select investments with due regard not only to quality but also to diversification and maturities, factors which must be

\footnotetext{
19 "Y. No compensation should be paid to members of the [State banking] board for their-services, but adequate provision should be made to cover the expenses they may incur while rendering such service.

"Comment: Since compensation sufficient to attract the type of man desired as a member of such a board cannot be paid, and since the offer of a stated sum might have the undesirable effect of attracting political job-seekers, it would seem that to provide compensation would be to defeat the purposes for which 2 banking board is created." Bankming Boards, Statutory and Fxctual Study (Research Council, Am. Bankers Ass'n, N. Y., 1938) 8.

14 "552. Superintendent must farnish savings banks list of legal investments. . . .

"The trustees of a savings bank shall not be held liable for investing in state or municipal bonds named in the last list furnished by the superintendent of banks pursuant to this section or in any obligations described in subdivisions seven, twelve or thirteen of section two hundred and thirty-nine of this chapter mentioned in such list, which have been legally issued and properly executed, unless such savings bank shall have been notified by the superintendent of banks, that in his judgment, such bonds do not conform or have ceased to conform to the provisions of section two hundred and thirty-nine of this chepter." Excerpt from N. Y. Banzung LAF, \$52.
} 
considered in the light of the needs of each particular trust. ${ }^{10}$ Such a policy is fundamental, no matter what method a state may use in preparing its legal list.

\section{SUMMARY}

Our basic problem in modernizing legal investment standards, today as in the past, is to provide a list which is broad enough to permit of judicious investment of the vast amount of funds which are held in a fiduciary capacity. The difficulty in achieving this objective has been emphasized by the economic and political developments of recent years. In reviewing the laws of different states we find numerous conflicting standards due, usually, to historical influence, rather than to well-defined policies designed to meet existing needs. A number of states which have statutory investment standards provide a list primarily for the use of savings banks but, as a matter of convenience, make the list also serve the purposes of trustees. Such a policy is unsound, not only because it fails to recognize that factors exist justifying different lists but also because it discourages corporate trustees from assuming responsibility for assisting in the maintenance of modern standards. Examination of generally accepted tests governing two important classes of securities, railroads and municipals, demonstrates the fundamental difficulty of attempting to prescribe fixed statutory standards which operate effectively to maintain a broad list which is reasonably free of inferior securities. Some states, desiring to maintain the principle of the statutory list but wishing to overcome the defect of inflexibility, have authorized a public official or board to exercise discretion in making additions to the legal list. This plan of qualifying investments has not been adequately tested by experience, nor is it free of criticism even in the states where it is being tried. Nevertheless, it suggests possibilities deserving of consideration, not as a plan to substitute the discretion and responsibility of the state for that of the trustee, but as the means of providing a more satisfactory list from which the trustee may select investments, subject always to the rule that he act with reasonable diligence, prudence, and in good faith.

Io "The trustee who invests in securities included in the statutory list is relieved by the West Virginia statute of all responsibility for subsequent losses. But four acts [Alabama, Delaware, Illinois and Minnesota] expressly impose the normal requirement of due care upon trustees who select or retain listed securities, and this result will probably be reached by construction in other states whose statutes are silent upon the subject. The desirability of blanket protection is questionable, since it is likely to invite a cursory study of investment conditions by the trustee. Although a duty of due care is required, he would still seem suffeiently protected under the acts. The existence of a statutory list avoids the unguided selection of a proper class of investments and reduces the problem to a reasonable choice within the permitted class. Moreover, the fact that the class of investment selected had reccived legislative approval would undoubtedly influence the court in determining that the trustee had exercised due carc." Note (1936) 49 HARv. L. REv. 82J, and cases there cited. 